\title{
Łukasz Buczkowski
}

\author{
Stwierdzanie ważności wyborów parlamentarnych \\ w myśl rozstrzygnięć Konstytucji Rzeczypospolitej Polskiej \\ z 2 kwietnia 1997 r. oraz Ordynacji wyborczej \\ do Sejmu RP i Senatu RP z 12 kwietnia 2001 r.
}

I.

Analiza postanowień kolejnych polskich Konstytucji i ustaw wyborczych pozwala stwierdzić, iż na gruncie polskiego prawa zastosowanie znalazło kilka spośród współcześnie występujących modeli kontroli ważności wyborów: parlamentarny, jurysdykcyjny oraz mieszany, dzielący kompetencje weryfikacyjne pomiędzy legislatywę i organ sądowy. W odniesieniu do każdego $\mathrm{z}$ nich sformułować można zarówno uwagi aprobujące poszczególne rozwiązania, jak i pewne wnioski krytyczne. Celem niniejszego artykułu jest prezentacja konstytucyjnych reguł ustalania ważności postępowania wyborczego do Sejmu i Senatu, znajdujących rozwinięcie w postanowieniach ordynacji parlamentarnej z dnia 12 kwietnia 2001 r., ze wskazaniem problemów, jakie niesie ze sobą próba praktycznego wykorzystania niektórych przepisów, składających się na przyjęty system weryfikacji wyborów.

Przed przystąpieniem do omówienia konstytucyjnych zasad stwierdzania ważności wyborów parlamentarnych, przyjętych przez obecnie obowiązującą Ustawę Zasadniczą, celowe wydaje się chociażby zwięzłe omówienie propozycji podniesionych $\mathrm{w}$ trakcie prac legislacyjnych nad ostatecznym kształtem Konstytucji, odnoszących się do zasad weryfikacji postępowania wyborczego do Sejmu i Senatu. Jest to zabieg tym bardziej uzasadniony, je-

Autor jest adiunktem w Katedrze Prawa Konstytucyjnego i Stosunków Międzynarodowych Wydziału Prawa i Administracji w Rzeszowie Wyższej Szkoły Prawa i Administracji w Przemyślu-Rzeszowie. 
śli wziąć pod uwagę, iż wniesione projekty Ustawy Zasadniczej wykazywały w interesującym nas zakresie istotne zróżnicowanie, zarówno jeśli chodzi o podmiot dokonujący weryfikacji ważności wyborów ${ }^{2}$, jak również dotyczące trybu dokonywania kontroli postępowania wyborczego oprotestowanego i takiego, przeciwko ważności którego nie zostały wniesione skargi ${ }^{3}$.

Projekty Polskiego Stronnictwa Ludowego / Unii Pracy oraz senacki przewidywały, iż organem dokonującym oceny ważności wyborów miał być parlament ${ }^{4}$ (oba projekty nie dokonywały przy tym rozróżnienia na wybory oprotestowane i nieoprotestowane), projekty obywatelski oraz Unii Demokratycznej / Unii Wolności ${ }^{5}$ przyznawały uprawnienia weryfikacyjne Sądowi Najwyższemu, zaś zgodnie z treścią projektów prezydenckiego i Stronnictwa Ludowo-Demokratycznego, ważność wyborów in toto stwierdzać miał parlament, zaś w razie wniesienia protestu przeciwko ważności wyboru posła, organem dokonującym weryfikacji miał być Trybunał Konstytucyjny ${ }^{6}$.

W pierwotnej wersji, odnoszący się do trybu stwierdzania ważności wyborów art. 88 Konstytucji, przedstawiony Podkomisji organów władzy w grudniu 1994 r. ${ }^{7}$ przewidywał sądową kontrolę jedynie w odniesieniu do mandatów zaprotestowanych ${ }^{8}$ : „1. Ważność wyboru posłów, przeciwko którym nie zgłoszono protestu, stwierdza Sejm. O ważności wyboru posła, przeciwko któremu zgłoszono protest, rozstrzyga Sąd Najwyższy (Trybunał Konstytucyjny)". Ustęp drugi zawierał analogiczne postanowienia w odniesieniu do senatorów. Wariantowe określenie organu dokonującego oceny ważności oprotestowanego wyboru posła utrzymało się do stycznia 1995 r., kiedy

2 Wśród organów, które miałyby dokonywać weryfikacji wyborów parlamentarnych wymieniano Sąd Najwyższy, Trybunał Konstytucyjny oraz właściwe izby.

3 R. Chruściak, Sejm i Senat w Konstytucji RP z 1997 r., Warszawa 2002, s. 78.

4 Por. Projekty Konstytucji 1993-97, opracowanie do druku R. Chruściak, Warszawa 1997, s. 153 i 201.

5 Projekt ten przewidywał stwierdzanie ważności wyborów oraz stwierdzanie ważności wyboru posła, przeciwko któremu wniesiono protest.

6 Projekty Konstytucji 1993-97..., s. 47, 108 i 116. Dodać należy, iż jedynie projekt Konstytucji w wersji przedstawionej przez Konfederację Polski Niepodległej nie odnosił się wprost do zagadnień związanych z ważnością wyborów parlamentarnych. Zgodnie z art. 105 Konstytucji wg projektu KPN, organem „sprawującym nadzór nad wyborami” miała być Rada Stanu.

7 R. Chruściak, op.cit., s. 79. Por. także Biuletyn Komisji Konstytucyjnej Zgromadzenia Narodowego nr X, s. 189.

8 Zob. A. Patrzałek, W. Skrzydło, Cele i zasady kodyfikacji prawa wyborczego w Polsce, „Przegląd Sejmowy” nr 2, 1997, s. 15. 
Komisja Konstytucyjna rozstrzygnęła ostatecznie, iż właściwy w sprawach ustalania ważności wyborów jest Sąd Najwyższy.

W dalszym toku prac centralnym punktem rozważań, dotyczących systemu ustalania prawomocności postępowania wyborczego, stało się rozstrzygnięcie problemu, czy w stosunku do wyborów niezaprotestowanych należy przyjąć domniemanie ich ważności (i pozostawić je poza kontrolą sądową), czy też bardziej celowe będzie dokonywanie weryfikacji wyborów jako takich, chociażby nie zgłoszono skarg przeciwko ich ważności

Komisja Konstytucyjna poleciła Podkomisji redakcyjnej przygotowanie nowego brzmienia art. 88, przy uwzględnieniu wynikających z przebiegu dyskusji wytycznych, stosownie do których należało przyjąć domniemanie ważności wyborów (zarówno w całości, jak też w odniesieniu do konkretnych posłów), przeciwko którym nie zostały wniesione protesty wyborcze ${ }^{10}$.

Eksperci przygotowali dwie wersje dyskutowanego przepisu: zgodnie $\mathrm{z}$ wariantem przedstawionym przez prof. M. Grzybowskiego :„1. Ważność wyboru posłów, wobec wyboru których nie zgłoszono protestu, stwierdza Sejm. O ważności wyboru posła, wobec którego zgłoszono protest, rozstrzyga Sąd Najwyższy. 2. Ważność wyborów, wobec których nie zgłoszono protestów, stwierdza Państwowa Komisja Wyborcza. O ważności wyborów, wobec których zgłoszono protest, rozstrzyga Sąd Najwyższy”.

W wersji przygotowanej przez prof. P. Sarneckiego art. 88 otrzymał brzmienie:

„1. Wyborcy przysługuje prawo zgłoszenia do Sądu Najwyższego protestu przeciwko ważności wyborów z powodów przewidzianych przez ustawy. 2. Ważność obsadzenia pozostałych mandatów poselskich stwierdza Sejm”.

W stosunku do obu przedstawionych propozycji zgłoszone zostały podczas obrad Podkomisji uwagi, co spowodowało przeniesienie dyskusji na następne posiedzenie. W jego trakcie nastąpił przełom w odniesieniu do zasad stwierdzania ważności wyborów do Sejmu i Senatu: zgodnie z przedstawioną koncepcją, ważność wyborów (jako takich) lub wyboru posłów, w stosunku do których wniesiono protesty wyborcze, stwierdzać miał Sąd Najwyższy $^{11}$. Celem takiego rozwiązania miało być wprowadzenie obligatoryjnej weryfikacji również wtedy, gdy przeciwko ważności wyborów nie zostały

\footnotetext{
9 Por. Biuletyny KK ZN: XXXVIII, s. 30-33 oraz XL, s. 32-36.

10 R. Chruściak, op.cit., s. 80.

11 Zob. Biuletyn KK ZN: XLI, s. 64.
} 
wniesione protesty. Prezentowane stanowisko wpłynęło na przyjęcie w dalszym toku prac legislacyjnych obowiązującej obecnie wersji przepisu określającego zasady stwierdzania ważności wyborów parlamentarnych ${ }^{12}$.

Uchwalona 2 kwietnia 1997 r. Konstytucja RP'13, zagadnieniom związanym ze stwierdzaniem ważności wyborów do Sejmu i Senatu poświęca art. 101. W ust. 1 powtórzono zasadę wyrażoną w Małej Konstytucji z 1992 r. ${ }^{14}$, zgodnie z którą stwierdzanie ważności wyborów do Sejmu i Senatu należy do Sądu Najwyższego. Ustęp drugi omawianego przepisu przyznaje wyborcy prawo wniesienia protestu przeciwko ważności wyborów na zasadach określonych w ustawie ${ }^{15}$.

Z konstrukcji art. 101 wynika konieczność ustanowienia dwóch procedur weryfikacji wyborów parlamentarnych: trybu stwierdzania ważności wyborów jako takich oraz zasad rozpatrywania protestów wyborczych. W pierwszym przypadku wyznaczony organ działa z urzędu, w drugim zaś - na wniosek uprawnionych podmiotów ${ }^{16}$. W obu sytuacjach ciałem wyłącznie uprawnionym przez Konstytucję do podejmowania rozstrzygnięć jest Sąd Najwyższy, zatem na gruncie ustawy zwykłej nie można uprawnień związanych z ustalaniem ważności wyborów oraz rozpatrywaniem protestów wyborczych powierzyć innym organom (sądom powszechnym, Trybunałowi Konstytucyjnemu czy Państwowej Komisji Wyborczej).

Użyte w treści art. 101 ust. 1 wyrażenie, zgodnie z którym ważność wyborów „stwierdza Sąd Najwyższy” różni się od określenia „rozstrzyga Sąd Najwyższy" zawartego w art. 5 Małej Konstytucji jedynie technicznie - nie ma wpływu na rzeczywisty przebieg postępowania, zmierzającego do wydania przedmiotowej uchwały. Inną sprawą jest ustalenie terminów, w których powinno nastąpić rozstrzygnięcie protestów wyborczych oraz wydanie uchwały stwierdzającej ważność (lub nieważność) wyborów. Konstytucja nie określa żadnego z tych terminów, powierzając ustawie szczegółowe ustalenie zasad rozstrzygania ważności postępowania wyborczego.

\footnotetext{
12 Biuletyn KK ZN: XLII, s. 38-39.

13 Dz.U. Nr 78, poz. 483 ze zm.

14 Dz.U. Nr 84, poz. 426 ze zm.

15 A. Józefowicz, Przesłanki prawne rozstrzygnięcia o ważności wyborów parlamentarnych, „Państwo i Prawo” nr 8, 1999, s. 3.

${ }_{16}$ L. Garlicki, Komentarz do art. 101 Konstytucji, [w:] Konstytucja Rzeczypospolitej Polskiej. Komentarz, t. I, pod red. L. Garlickiego, Warszawa 1999, s. 2.
} 
Zadaniem Sądu jest ustalenie, czy postępowanie wyborcze zostało przeprowadzone zgodnie $\mathrm{z}$ obowiązującymi normami, tj. zbadanie czy nie wystąpiły w jego trakcie przypadki naruszeń prawa, na skutek których mandaty przedstawicielskie przypadły innym osobom, niż by to wynikało z ustaleń dokonanych na podstawie prawidłowo przeprowadzonych wyborów. Za zasadę przyjąć należy przy tym domniemanie ważności przeprowadzonego postępowania wyborczego, zatem ewentualne jego unieważnienie w skali kraju, okręgu lub w odniesieniu do wyboru pojedynczych posłów lub senatorów musi się opierać na potwierdzeniu zarzutów zgłoszonych w trakcie procesu weryfikacji.

Kilku słów komentarza wymaga charakter prawny uchwał Sądu Najwyższego odnoszących się do stwierdzenia ważności lub nieważności wyborów (wyboru). Zgodnie z zasadą domniemania legalności postępowania wyborczego, uchwała stwierdzająca ważność wyborów zawsze będzie miała charakter deklaratoryjny, nie wpływa bowiem na istniejącą sytuację prawną izb oraz konkretnych posłów i senatorów: tryb funkcjonowania parlamentu oraz uprawnienia przedstawicielskie ich członków nie ulegają przemianom w wyniku wydania uchwały potwierdzającej ważność wyborów, bowiem parlament in corpore oraz konkretni parlamentarzyści wchodzą w ogół praw i obowiązków z chwilą ukonstytuowania się izb, nie zaś z chwilą wydania uchwały przez Sąd Najwyższy. A contrario, uchwała stwierdzająca nieważność wyborów w całości, w okręgu lub w odniesieniu do konkretnego posła lub senatora, $\mathrm{z}$ racji swych skutków (wygaśnięcie mandatów przedstawicielskich w zakresie unieważnienia) ma charakter konstytutywny i wymusza podjęcie działań zmierzających do ukształtowania zgodnego z prawem składu izb - bądź to poprzez przeprowadzenie wyborów ponownych, bądź przez podjęcie na nowo określonych czynności postępowania wyborczego.

\section{II.}

Potrzeba wprowadzenia przekształceń w prawie wyborczym do parlamentu zarysowała się szczególnie wyraźnie po uchwaleniu w kwietniu 1997 r. nowej Konstytucji, do której postanowień należało dostosować obowiązujące ordynacje oraz po dokonaniu w 1998 r. zasadniczych przekształceń w podziale terytorialnym kraju, skutkujących koniecznością ustalenia nowego 
podziału na okręgi wyborcze w wyborach do Sejmu, jak również potrzeba wypracowania zasad systemu wyborczego do Senatu ${ }^{17}$.

Pierwszy projekt zmian w obrębie postępowania wyborczego do Sejmu i Senatu złożony został w lipcu 1999 r. (SLD), następne zaś (PSL, AWS-SKL, UW, projekt senacki) zgłoszono do września tego roku. Pomimo tego, ostateczną decyzję o uchwaleniu nowej ordynacji podjęto dopiero w maju 2000 r., samą zaś ustawę wyborczą przyjęto - co do 2006 r. stanowiło nawyk polskiego ustawodawcy - na krótko przed wyborami parlamentarnymi - 12 kwietnia $2001 \mathrm{r}$.

Zagadnieniom związanym $\mathrm{z}$ weryfikacją ważności wyborów parlamentarnych ustawa z dnia 12 kwietnia 2001 r. poświęciła Rozdział X, zawierający tożsame dla obu izb przepisy, określające: zakres przedmiotowy protestu, podmioty uprawnione do jego wniesienia, uczestników oraz tryb postępowania sądowego, jak również możliwe rozstrzygnięcia co do ważności postępowania wyborczego. Należy zauważyć, iż omawiane przepisy ordynacji cechuje duża stabilność: od momentu uchwalenia ustawy wyborczej, jej Rozdział X był nowelizowany zaledwie dwa razy, przy czym obie zmiany można określić jako kosmetyczne ${ }^{18}$, co w zestawieniu z jedenastokrotną, często bardzo szeroką interwencją ustawodawcy w treść ordynacji, pozwala je uznać choć nie bez wyjątków - za nie budzące większych wątpliwości.

Zgodnie z obowiązującym stanem prawnym, protest przeciwko ważności wyborów parlamentarnych, może przyjąć następujące formy:

17 Odzwierciedlenie procesu legislacyjnego poprzedzającego przyjęcie ordynacji z 2001 r. zawierają: Sprawozdanie stenograficzne z 59 posiedzenia Sejmu RP w dniu 8 października 1999 r.; Sprawozdanie stenograficzne ze 101 pos. Sejmu RP w dniu 16 lutego 2001 r.; Sprawozdanie stenograficzne ze 103 pos. Sejmu RP w dniu 7 marca 2001 r. oraz Sprawozdanie stenograficzne ze 106 pos. Sejmu RP w dniu 12 kwietnia 2001 r. Zob. także S. Gebethner, Wybory do Sejmu i do Senatu. Komentarz do Ustawy z dnia 12 kwietnia 2001 r. - Ordynacja wyborcza do Sejmu Rzeczypospolitej Polskiej i do Senatu Rzeczypospolitej Polskiej, Warszawa 2001, s. XV oraz A. Antoszewski, Ewolucja systemu wyborczego do Sejmu, [w:] Demokratyzacja w III Rzeczypospolitej, pod red. A. Antoszewskiego, Wrocław 2002, s. 69.

18 Art. 82 ust. 1 Ordynacji został znowelizowany przez art. 73 ustawy z dnia 30 sierpnia 2002 r. - Przepisy wprowadzające ustawę - Prawo o ustroju sądów administracyjnych i ustawę - Prawo o postępowaniu przed sądami administracyjnymi (Dz.U. Nr 153, poz. 1271), na mocy którego SN o ważności wyborów rozstrzyga w składzie całej Izby Pracy, Ubezpieczeń Społecznych i Spraw Publicznych w miejsce dawnej Izby Administracyjnej, Pracy i Ubezpieczeń Społecznych; treść art. 79. ust. 1 znowelizowała zaś Ustawa z dnia 12 czerwca 2003 r. - Prawo pocztowe (Dz.U. Nr 130, poz. 1188), na mocy której określenie „polski urząd pocztowy” zmieniono na „polską placówkę pocztową operatora publicznego”. 
- $\quad$ protestu przeciwko ważności wyborów do Sejmu lub Senatu w całości,

- protestu przeciwko ważności wyborów w określonym okręgu wyborczym

- $\quad$ protestu przeciwko wyborowi konkretnego posła bądź senatora' ${ }^{19}$.

Materialnoprawnymi przesłankami wniesienia protestu są, zgodnie z treścią art. 78 ust. 1 ordynacji:

- $\quad$ dopuszczenie się przestępstwa przeciw wyborom, przy czym przez przestępstwa takie należy rozumieć typy czynów zabronionych, wyczerpujące znamiona określone w art. 248-251 części szczególnej kodeksu karnego z 1997 r., w Rozdziale XXXI ${ }^{20}$ „Przestępstwa przeciwko wyborom i referendum”, stojącym na straży dwóch podstawowych instytucji ustroju demokratycznego ${ }^{21}$. Przestępstwa te, polegają na: fałszowaniu dokumentów wyborczych (248 k. k.), opartym na groźbie bezprawnej, przemocy lub podstępie przeszkadzaniu w prawidłowym przebiegu postępowania wyborczego ( $249 \mathrm{k}$. k.), wywieraniu wpływu lub zmuszaniu uprawnionego do głosowania, głosowania w określony sposób lub do powstrzymania się od głosowania (250 k. k.), korupcji wyborczej (250a k. k.) $)^{22}$ lub naruszeniu przepisów o tajności głosowania (251 k. k.). Jedynie wskazane powyżej typy czynów

19 K. Krzekotowska, Prawo wyborcze, Bielsko-Biała 2005, s. 29.

20 Kodeks wyborczy uchwalony przez Sejm dnia 3 grudnia 2010 r. (wersja przed stanowiskiem Senatu), odnosząc się do podstaw protestów wyborczych - odmiennie niż ordynacja parlamentarna z dnia 12 kwietnia 2001 r. - expressis verbis wskazuje, że przesłanką wniesienia protestu może być dopuszczenie się przestępstwa przeciwko wyborom określonego w Rozdziale XXXI k. k. (art. $78 \$ 1)$.

21 L. Tyszkiewicz, Uwagi wstępne do Rozdziału XXXI k. k. z 1997 r., [w:] Kodeks karny. Komentarz, pod red. O. Górnioka, Warszawa 2004, s. 718.

22 Początkowo w treści Rozdziału XXXI k. k. pominięto przestępstwo korupcji wyborczej - brak ten został usunięty na mocy nowelizacji z dnia 13 czerwca 2003 r. (Dz.U. Nr 111, poz. 1061), wprowadzającej art. 250a. Omawiany artykuł rozróżnia łapownictwo wyborcze bierne, czyli tzw. sprzedajność wyborczą (art. 250a \$1 k. k.) oraz łapownictwo wyborcze czynne - czyli przekupstwo wyborcze (art. 250a $\$ 2 \mathrm{k} . \mathrm{k}$ ), co odpowiada częściowo konstrukcji występującej na gruncie k. k. z 1932 r. (art. 121 i 122). Pominięto natomiast przewidziane w kodeksie Makarewicza warianty polegające na udzielaniu i przyjmowaniu korzyści w zamian za powstrzymanie się od głosowania oraz tzw. przekupstwo pośrednie. Zob. L. Tyszkiewicz, Komentarz do art. 250a k. k., [w:] Kodeks karny. Komentarz, pod red. M. Filara, Warszawa 2008, s. 965 oraz R. A. Stefański, Przestępstwo korupcji wyborczej (art. 250a k. k.), „Prokuratura i Prawo” nr 4, 2004, s. 69. 
zabronionych mogą stanowić podstawę protestu wyborczego, opartego na zarzucie popełnienia przestępstwa przeciwko wyborom. Skarga wyborcza nie może natomiast opierać się na naruszeniu przepisów karnych określonych w Rozdziale 35 ordynacji, nie stanowią one bowiem przestępstw przeciwko wyborom w rozumieniu kodeksu karnego ${ }^{23}$.

- $\quad$ naruszenie przepisów ustawy wyborczej dotyczących przebiegu głosowania, ustalenia jego wyników, jak również ustalenia wyników wyborów ${ }^{24}$ (naruszenia innych przepisów ustawy wyborczej ${ }^{25}$ nie mogą stanowić podstawy protestu, chociażby wywarły wpływ na wynik wyborów. Podstawą protestu nie może być również zarzut przeciwko treści przepisów ordynacji. W takiej sytuacji możliwe jest zainicjowanie postępowania przed Trybunałem Konstytucyjnym w drodze skargi konstytucyjnej).

Należy zwrócić uwagę na wątpliwości, jakie nasuwają się w związku z ustawowym ograniczeniem podstaw ewentualnych protestów wyborczych do takich naruszeń przepisów ordynacji, które odnoszą się jedynie do przebiegu głosowania lub ustalenia wyników głosowania i wyników wyborów. Jak wskazano wyżej, art. 101 ust. 2 Konstytucji, przyznaje wyborcy prawo zgłoszenia protestu przeciwko ważności wyborów na zasadach określonych w ustawie. Wyrażenie to powinno być rozumiane tak samo jak pojęcie ważności wyborów z art. 101 ust. 1 Ustawy Zasadniczej, tj. jako odnoszące się do ogółu czynności postępowania wyborczego. Krytycznie zatem należy spojrzeć na ograniczenie dopuszczalnych podstaw protestów jedynie do zarzutów złamania ściśle wskazanych przepisów ustawy wyborczej, przy jednoczesnym wyeliminowaniu jako podstawy skargi wszelkich innych naruszeń prawa wyborczego, choćby możliwe było wykazanie ich wpływu na wyni-

\footnotetext{
23 S. Gebethner, op.cit., s. 103.

$24 \mathrm{Z}$ konstrukcji art. 78 ust. 1 ordynacji wynika, iż protest dotyczyć może jedynie tego etapu postępowania wyborczego, który został zapoczątkowany aktem głosowania. Por. J. Repel, Weryfikacja wyborów parlamentarnych $w$ polskim prawie konstytucyjnym, [w:] Przeobrażenia we wspótczesnym prawie konstytucyjnym, pod red. K. Działochy, Wrocław 1995, s. 127.

25 J. Buczkowski, Podstawowe zasady prawa wyborczego III Rzeczypospolitej, Lublin 1998, s. 293. Zob. także J. Mordwiłko, Protesty wyborcze w świetle ordynacji wyborczej z 1993 r. do Sejmu RP oraz praktyka ich rozpoznawania, „Państwo i Prawo” z. 1, 1995, s. 37.
} 
ki wyborów ${ }^{26}$. Jak trafnie zauważa L. Garlicki: „upoważnienie ustawodawcy zwykłego do określenia zasad zgłaszania protestów wyborczych dotyczy sfery proceduralnej, a nie może dawać podstaw do ograniczania samej istoty instytucji protestu wyborczego"27.

Z powyższych uwag wynikają dwa wnioski: po pierwsze, protest wyborczy, zgodnie z dyspozycją art. 101 ust. 2 Konstytucji może zostać wniesiony jedynie przeciwko ważności wyborów, co wyklucza dopuszczalność skargi opartej na zarzutach w stosunku do czynności, które nie wywarły wpływu na prawidłowy przebieg postępowania wyborczego w ten sposób, że zasadne byłoby jego unieważnienie ${ }^{28}$, po drugie zaś, wydaje się, że z treści omawianego przepisu wynika dopuszczalność oparcia protestu wyborczego na zarzutach odnoszących się do wszelkiego rodzaju czynności wyborczych, wpływających na ważność wyborów w sposób „wiarygodny, udokumentowany i sprawdzalny"29. Ustawowe zawężenie podstaw skarg do naruszeń przepisów związanych jedynie z głosowaniem, ustalaniem wyników głosowania oraz ustalaniem wyników wyborów, należy uznać za niezrozumiałe ograniczenie zakresu kontroli ważności postępowania wyborczego. Omawiane zagadnienie wielokrotnie stawało się przedmiotem kontrowersji w doktrynie prawa konstytucyjnego.

Z. Jarosz twierdzi, iż dyskutowane ograniczenie stanowi przykład selektywnego traktowania praworządności wyborczej, wyłączającego spod kontroli sądowej naruszenia innych przepisów ustawy, choćby miały one istotny wpływ na wynik wyborów. Autor ten zauważa również, że z zestawienia treści art. 78 ust. 1 (ograniczenie zakresu przedmiotowego protestów wyborczych) oraz art. 81 ust. 2, zgodnie z którym SN pozostawia bez dalszego biegu protest dotyczący sprawy, w której ustawa przewiduje możliwość wniesienia skargi lub odwołania do sądu lub PKW przed dniem głosowa-

26 Odmiennie na ten temat Z. Szonert, który twierdzi, iż „zakres przedmiotowy kontroli czynności wyborczych jest wynikiem racjonalnego kompromisu między różnymi formami kontroli czynności wyborczych i wyników wyborów sprawowanej przez państwowe organy wyborcze, społeczne formy kontroli i nadzór sądowy”. Por. Z. Szonert, Sądowa kontrola procedur wyborczych, wyników wyborów i referendów, [w:] Demokratyczne prawo wyborcze Rzeczypospolitej Polskiej (1990-2000), pod red. F. Rymarza, Warszawa 2000, s. 57 i n.

27 L. Garlicki, op.cit., s. 5 i n.

28 Ibidem, s. 5.

29 Uchwała Izby Administracyjnej, Pracy i Ubezpieczeń Społecznych SN z dnia 9 grudnia 1995 r., III SW 1102/95, OSNAP 1996, nr 1, poz. 1. 
nia, wynika błąd w technice legislacyjnej: w obliczu ograniczenia ustanowionego w art. 78 ust. 1, art. 81 ust. 2 uznać należy za prawodawcze superfluum $^{30}$. J. Repel prezentuje natomiast pogląd, iż intencją ustawodawcy było wyłączenie z procesu weryfikacji wyborów przez SN sytuacji, które mogły być rozstrzygnięte wcześniej z woli wyborcy - należy bowiem zauważyć, iż ograniczenie podstaw skarg wyborczych nie przesądza o całkowitym wyłączeniu spod kontroli innych czynności postępowania wyborczego - część z nich (np. nieprawidłowości w rejestrze wyborców, rejestracja list wyborczych, czy naruszenia zasad prowadzenia kampanii wyborczej) podlega kontroli dokonywanej przez PKW lub sąd powszechny ${ }^{31}$. Podobne stanowisko wyraża K. Gołyński twierdząc, iż pozostawienie bez dalszego biegu protestów w sprawach, w których przewidziano w ustawie możliwość wniesienia skargi lub odwołania do PKW lub sądu zinterpretować można jako „wyraźne wyłączenie możliwości traktowania protestu jako środka podważania już,,skonsumowanych" czynności wyborczych"32. Nie przekreśla to jednak ogólnej negatywnej oceny zawężenia podstaw protestu wyborczego na gruncie ordynacji parlamentarnej - kontroli sprawowanej przez sądy lub PKW poddano bowiem jedynie nieliczne instytucje postępowania wyborczego, wyłączone z mocy art. 78 ust. 1 jako podstawy skarg wyborczych.

Przy okazji analizy materialnych przesłanek protestów wyborczych, należy zwrócić uwagę na budzące wątpliwości rozwiązanie, przewidziane w uchwalonym dnia 3 grudnia 2010 r. kodeksie wyborczym. Pomimo, iż akt ten nie uzyskał jeszcze mocy obowiązującej, celowe wydaje się zasygnalizowanie problemów, jakie może rodzić redakcja art. $78 \$ 1$ pkt 1 i 2 ustawy. Kodeks wyborczy, odnosząc się w treści przywołanych przepisów do podstaw protestów wyborczych stanowi, iż zaskarżenie ważności wyborów, wyborów w okręgu lub wyboru określonej osoby możliwe jest z powodu dopuszczenia się przestępstwa wyborczego lub naruszenia przepisów ustawy dotyczących głosowania, ustalenia wyników głosowania lub ustalenia wyników wyborów, mających wpływ na wynik wyborów. Konstrukcja ta przypomina poddawane krytyce rozwiązania, obowiązujące na gruncie ordynacji wyborczych do Sejmu z 1989 oraz 1991 r. Nie wydaje się logiczne wiązanie

30 Por. Z. Jarosz, Nowa ordynacja wyborcza do Sejmu RP, „Państwo i Prawo” z. 7, 1993, s. 17.

Zob. J. Repel, op.cit., s. 127

K. Gołyński, Prawa wyborcze w praktyce, Warszawa 1995, s. 16. 
dopuszczalności złożenia protestu z jego wpływem na ostateczny wynik wyborów: ustalenie związku przyczynowo-skutkowego pomiędzy postawą protestu a wynikami elekcji nie jest zadaniem skarżącego (który na dodatek nie dysponuje żadnymi środkami pozwalającymi mu na dokonanie takiej wiążącej oceny), ale organu odpowiedzialnego za stwierdzenie ważności wyborów. Obecny kształt art. $78 \$ 1$ pkt 1 i 2 kodeksu dopuszcza interpretację sprzeczną z obowiązującym modelem weryfikacji wyborów, wyrażającą się w przerzuceniu na składającego protest obowiązku wykazania, czy zaobserwowane naruszenia prawa wywarły wpływ na wynik postępowania wyborczego, czy też nie ${ }^{33}$. Aby uniknąć wątpliwości co do właściwego rozumienia omawianych przepisów nowej regulacji, uzasadnione wydaje się przeredagowanie ich treści.

Katalog podmiotów wyposażonych w uprawnienie do wniesienia protestu wyborczego w wyborach parlamentarnych różnicuje podstawa, na jakiej zostało zgłoszone zastrzeżenie co do prawidłowości przebiegu postępowania wyborczego. Generalna legitymacja, przysługująca każdemu wyborcy (prawo do złożenia protestu nie jest uzależnione od faktycznego udziału w wyborach), czyniącemu zadość warunkom określonym w art. 62 Konstytucji oraz w art. art. 6 i 7 ordynacji, tj. spełniającemu cenzus wieku (pełnoletności) - przy założeniu, iż nie zachodzi względem niego żadna z przesłanek ujemnych w postaci prawomocnego ubezwłasnowolnienia, pozbawienia praw publicznych lub wyborczych - odnosi się jedynie do protestów mających za podstawę zarzut popełnienia przestępstwa przeciwko wyborom lub naruszenia przepisów ordynacji dotyczących ustalenia wyników głosowania lub wyników wyborów, dokonane - zdaniem skarżącego - przez Państwową Komisję Wyborczą. W imieniu uprawnionego, protest wyborczy może wnieść jego pełnomocnik. Zastępstwo procesowe w sprawach protestów wyborczych pełnić mogą osoby wymienione w art. $87 \$ 1 \mathrm{k}$. p. c., z wyjątkiem osoby sprawującej zarząd majątkiem lub interesami strony oraz osoby pozostającej ze stroną w stałym stosunku zlecenia, ponieważ przedmiotem protestu są podmiotowe prawa publiczne wnoszącego skargę, nie zaś jego prawa majątkowe ${ }^{34}$.

33 Ibidem, s. 25.

34 Zob. A. Józefowicz, Regulacja prawna protestu przeciwko ważności referendum konstytucyjnego, „Państwo i Prawo” nr 6, 1997, s. 24 oraz T. Flemming-Kulesza, A. Filcek, Postępowanie przed Sądem Najwyższym w sprawach protestów wyborczych, [w:] Wybory 93. Opracowania 
W przypadku zgłoszenia zarzutów co do ważności postępowania wyborczego w okręgu lub zakwestionowania ważności wyboru konkretnego posła lub senatora, uprawnienie do złożenia protestu przysługuje wyłącznie wyborcy, który w dniu wyborów figurował w spisie wyborców jednego z obwodów należących do danego okręgu wyborczego ${ }^{35}$. Należy również zauważyć, iż legitymowani do zgłoszenia protestu wyborczego - zgodnie $\mathrm{z}$ art. 78 ust 4 ordynacji - są również przewodniczący właściwej komisji wyborczej oraz pełnomocnik wyborczy komitetu wyborczego ${ }^{36}$. Ustawa nie wskazuje szczegółowo, w jakim zakresie przewodniczący właściwej (obwodowej lub okręgowej) komisji wyborczej oraz pełnomocnik komitetu wyborczego mogą zaskarżyć postępowanie wyborcze - pewne jest, iż ogólnie przysługują im takie same uprawnienia, jak pozostałym wyborcom, na zasadach ustalonych w ordynacji. Wydaje się zasadne przyjęcie, że pełnomocnikowi lokalnego komitetu wyborczego, zgłaszającego kandydata na senatora w jednym okręgu wyborczym, przysługuje prawo wniesienia protestu przeciwko ważności wyborów lub przeciwko ważności wyboru konkretnego senatora jedynie w okręgu, na terenie którego działa komitet, zaś w przypadku pełnomocnika komitetu ogólnopolskiego (takiego, który zarejestrował listy okręgowe lub kandydatów na senatorów w co najmniej połowie okręgów wyborczych) - również uprawnienie do zaskarżenia wyborów w całości ${ }^{37}$.

sędziów Sądu Najwyższego dotyczące interpretacji ustawy z dnia 28 maja 1993 r. - Ordynacja wyborcza do Sejmu RP $i$ ustawy z dnia 10 maja 1991 r. - Ordynacja wyborcza do Senatu RP $w$ zakresie rozpoznawania protestów wyborczych i podejmowania uchwat $w$ sprawie ważności wyborów, Warszawa 1993, s. 54. Należy zauważyć, że kodeks wyborczy z dnia 3 grudnia 2010 r. (przed stanowiskiem Senatu), zakreślając katalog uprawnionych do wniesienia protestu stanowi, iż „protest przeciwko ważności wyborów z powodu dopuszczenia się przestępstwa przeciwko wyborom, o którym mowa w $\$ 1$, lub naruszenia przez właściwy organ wyborczy przepisów kodeksu dotyczących głosowania, ustalenia wyników głosowania lub wyników wyborów może wnieść wyborca, którego nazwisko w dniu wyborów było umieszczone w spisie wyborców w jednym z obwodów głosowania” (art. 78 \$2).

35 J. Mordwiłko, op.cit., s. 37. Podkreślić należy, iż na zasadzie współuczestnictwa materialnego, określonego w art. $72 \$ 1$ pkt 1 k. p. c. dopuszczalne jest wniesienie protestu w jednej sprawie przez kilka osób łącznie, na tej samej podstawie faktycznej i prawnej. Por. A. Józefowicz, Przestanki..., s. 5 oraz K. Gołyński, op.cit., s. 21.

36 W. Skrzydło, hasło „ważność wyborów do Sejmu i Senatu”, [w:] Konstytucja Rzeczypospolitej Polskiej. Komentarz encyklopedyczny, pod red. W. Skrzydły, S. Grabowskiej, R. Grabowskiego, Warszawa 2009, s. 618. Zob. także: K. Krzekotowska, op.cit., s. 29; Z. Szonert, op.cit., s. 57.

37 S. Gebethner, op.cit., s. 104. 
W odniesieniu do przewodniczącego właściwej komisji wyborczej, należy stwierdzić, iż sprawującemu tę funkcję, przysługuje prawo do wniesienia protestu przeciwko ważności wyborów w okręgu, w którym działa dana komisja lub przeciwko ważności wyboru posła (senatora), ubiegającego się o wybór z tego okręgu. Uprawnienie to, prowokujące pytania co do jego celowości (przewodniczącym komisji wyborczych przysługują przecież takie same uprawnienia w zakresie zaskarżania wyborów, jak ogółowi uprawnionych), tłumaczy się chęcią zapewnienia prawa złożenia protestu w imieniu komisji niższego stopnia w sytuacji, gdyby w procesie ustalania wyników wyborów komisja okręgowa lub Państwowa Komisja Wyborcza podjęły działania wadliwe albo też, gdyby w trakcie przekazywania protokołów popełnione zostało przestępstwo przeciwko wyborom ${ }^{38}$.

Samo złożenie protestu wyborczego nie skutkuje negatywnymi konsekwencjami dla wyłonionych przedstawicieli, stąd też do momentu rozstrzygnięcia przez Sąd Najwyższy o zasadności zgłoszonych zarzutów (a następnie o ważności wyborów), do osób, które w wyniku przeprowadzonego postępowania wyborczego uzyskały mandat przedstawicielski, stosuje się przepisy o obowiązkach i prawach posłów i senatorów.

Istnienie materialnych przesłanek protestu wyborczego, jak również legitymacji do jego wniesienia, nie przesądza jeszcze o wszczęciu postępowania sądowego - prawidłowo wniesiony protest wyborczy musi również sprostać przesłankom natury formalnoprawnej. Podkreśla się, iż protest wyborczy jest pismem posiadającym określoną nazwę i znaczenie prawne, dlatego też - jak każde pismo procesowe kierowane do sądu - musi odpowiadać warunkom określonym w ustawie, zaś treść zawartych w nim zarzutów i wniosków jest ściśle określona w przepisach prawa. W odniesieniu do warunków formalnych protestów wyborczych, przewidzianych w polskim prawie konstytucyjnym, w braku szczegółowych unormowań w aktach prawa wyborczego, odpowiednie zastosowanie znajdują przepisy kodeksu postępowania cywil-

38 Ibidem, s. 105. Zob. także A. Rakowska, K. Skotnicki, Udział komisarzy wyborczych $w$ rozpoznawaniu protestów wyborczych (referat złożony do protokołu narady PKW z komisarzami wyborczymi oraz dyrektorami zespołów i delegatur Krajowego Biura Wyborczego, odbytej w dniach 29-30 września 2008 r. w Szydłowie), „Przegląd Wyborczy” nr 9-10, 2008, s. 29. Dodatkowo należy podkreślić, iż pod rządami uprzednio obowiązującej ustawy wyborczej, przewodniczącym komisji wyborczych nie przysługiwało prawo wniesienia protestu przeciwko ważności wyborów. Uprawnienie o podobnym charakterze wprowadza ustawa o wyborze Prezydenta RP z 1990 r., przyznając je komisjom wyborczym. 
nego (pismo powinno w szczególności zawierać: dane osobowe oraz adres zamieszkania skarżącego oraz jego pełnomocnika, wskazanie SN jako adresata protestu, oświadczenie o faktach lub zdarzeniach, mających znaczenie prawne dla oceny ważności wyborów oraz dowody na poparcie wskazanych okoliczności i twierdzeń ${ }^{39}$. Przepisy obowiązującej ordynacji nakazują wniesienie protestu wyborczego do Sądu Najwyższego:

- w formie pisemnej,

- w terminie 7 dni od dnia ogłoszenia wyników wyborów ${ }^{40}$ przez Państwową Komisję Wyborczą w Dzienniku Ustaw RP (termin wskazany przez ustawę jest terminem zawitym i niedopuszczalne jest jego przywrócenie [art. 81 ust. 1 ordynacji].

Uchybienie terminowi powoduje skutki materialnoprawne, wyrażające się w utracie prawa do wniesienia protestu. Należy podkreślić, iż termin uznaje się za zachowany, jeśli skarżący w czasie jego biegu, nadał protest w polskiej placówce pocztowej. Ustawa reguluje również uprawnienia osoby legitymowanej do wniesienia protestu wyborczego, a przebywającej w czasie biegu terminu za granicą lub na polskim statku morskim: w przypadkach tych, warunkiem uznania prawidłowości wniesienia protestu jest jego złożenie odpowiedniemu terytorialnie konsulowi lub kapitanowi statku [wyborca może oczywiście zrezygnować z takiego sposobu złożenia protestu i przesłać go bezpośrednio do SN, jednakże działanie takie obarczone jest wysokim ryzykiem uchybienia terminowi]. Skarżący jest ponadto obowiązany do ustanowienia w kraju pełnomocnika lub pełnomocnika do doręczeń [zawiadomienie o ustanowieniu dołącza się do protestu]. Uchybienie temu obowiązkowi skutkuje pozostawieniem protestu bez biegu. W odniesieniu do ustanowienia pełnomocnika aktualne pozostają uwagi przedstawione powyżej - nie może nim zostać osoba pozostająca ze stroną w stosunku zlecenia oraz prowadząca jej interesy lub sprawująca zarząd majątku strony. Pełnomocnikiem do doręczeń pism sądowych może zostać każda dorosła osoba zamieszkała w kraju) ${ }^{41}$, ze wskazaniem zarzutów oraz dowodów na ich

39 Zob. A. Józefowicz, Regulacja..., s. 23.

$40 \mathrm{Z}$ treści art. 78 ust. 1 wynika, iż protest skierowany jest przeciwko ważności wyborów, dlatego też może zostać wniesiony dopiero po zakończeniu postępowania wyborczego i ogłoszeniu jego wyników. Protest przedwczesny (zob. np. sprawa o sygn. akt III SW 4/93) zostanie pozostawiony bez dalszego biegu. Zob. K. Gołyński, op.cit., s. 25.

${ }^{41}$ Z. Szonert, op.cit., s. 58. Por. A. Józefowicz, Regulacja..., s. 25 oraz K. Gołyński, op.cit., s. 24. 
poparcie (ordynacja wyborcza z 2001 r. nie przewiduje możliwości wyznaczenia skarżącemu dodatkowego terminu do uzupełnienia braków protestu, polegających na nieprecyzyjnym określeniu zarzutów lub nieprzedstawieniu dowodów na ich poparcie. Protesty takie nie zostaną przez Sąd Najwyższy rozpatrzone. Usunięcie ww. braków jest możliwe z inicjatywy wnoszącego protest, bez uprzedniego wezwania, jedynie przed końcem terminu wynikającego z art. 79 ust. 1 [por. Uchwałę 7 sędziów SN z 28 sierpnia 1993 r., sygn. akt III SW 1/93]. Po upływie terminu nie jest również dopuszczalna zmiana lub zgłoszenie nowych zarzutów - jak jednak słusznie zauważa K. Gołyński, zgodnie z zasadą dążenia do wszechstronnego zbadania i wyjaśnienia okoliczności sprawy oraz rzeczywistej treści stosunków faktycznych i prawnych (art. $3 \$ 2$ k. p. c.) ograniczenie to nie dotyczy zgłaszania nowych dowodów (do znaczenia ustawowego wyrażenia „dowody” [na poparcie zarzutów protestu] odniósł się SN w postanowieniu wydanym w sprawie III SW 70/93, zajmując stanowisko, iż pojęcie to musi być rozumiane szeroko, w sposób wykraczający poza zwykłe rozumienie „środków dowodowych”). Skarżący nie ma natomiast obowiązku dokonywania oceny wpływu podnoszonych w proteście naruszeń prawa na wynik wyborów - stanowi to przedmiot postępowania przed SN, który z urzędu ustala związek zachodzący pomiędzy podstawą protestu a ostatecznym wynikiem wyborów ${ }^{42}$.

Wstępne badanie wniesionego protestu wyborczego należy do przewodniczącego wydziału - w toku przeprowadzanych czynności należy w pierwszym rzędzie ustalić, czy złożone pismo jest w istocie protestem wyborczym $\mathrm{w}$ rozumieniu przepisów ustawy ${ }^{43}$. Protestem jest bowiem tylko takie pismo procesowe, w którym kwestionuje się ważność wyborów, ważność wyborów w okręgu lub ważność wyboru posła - samo zatytułowanie pisma jako „protestu” nie ma tu decydującego znaczenia (również brak takiego oznaczenia, zgodnie z treścią art. $130 \$ 1$ zdanie drugie k. p. c. nie dyskwalifikuje dokumentu i nie wyłącza możliwości jego rozpatrzenia). Jeśli $z$ treści pisma nie można odczytać intencji wnoszącego do zakwestionowania ważności wyborów lub wyboru, należy takie pismo zwrócić bez zakładania akt ${ }^{44}$. Wstępne badanie obejmuje sprawdzenie, czy wniesione pismo odpowiada warunkom

42 Por. J. Kwaśniewski, Materialnoprawne przesłanki protestu wyborczego, [w:] Wybory 93..., s. 85, K. Gołyński, op.cit., s. 27. oraz J. Mordwiłko, op.cit., s. 40.

43 T. Flemming-Kulesza, A. Filcek, op.cit., s. 55.

44 Ibidem, s. 55. 
określonym w art. 126 i 128 k. p. c. - w razie wystąpienia braków, koniecznym staje się zastosowanie art. 130 k. p. c., tj. wezwanie skarżącego do ich uzupełnienia $\mathrm{w}$ terminie tygodniowym, pod rygorem zwrotu protestu ${ }^{45}$. Po pozytywnym wyniku badania wstępnego, przewodniczący wydziału wyznacza referenta i kieruje sprawę do rozpoznania na posiedzeniu niejawnym.

Postępowanie przed Sądem Najwyższym, mające na celu stwierdzenie ważności wyborów, przebiega dwuetapowo. W pierwszej kolejności, w postępowaniu opiniodawczym, zadaniem SN jest wyrażenie stanowiska co do zasadności wniesionych protestó $\mathrm{w}^{46}$, a w razie jej potwierdzenia - sformułowanie opinii w sprawie wpływu stwierdzonych naruszeń na wynik wyborów ${ }^{47}$. Następnie Sąd Najwyższy - w składzie całej Izby Pracy, Ubezpieczeń Społecznych i Spraw Publicznych - podejmuje uchwałę w sprawie ważności wyborów in toto ${ }^{48}$ oraz ważności zaskarżonego wyboru posła (senatora).

Prawidłowo wniesione protesty (w przypadku, gdy podstawę protestu wyborczego stanowi przestępstwo przeciwko wyborom, na SN spoczywa, zgodnie z art. 81 ust. 3 ordynacji, obowiązek niezwłocznego powiadomienia Prokuratora Generalnego, którego zadaniem jest spowodowanie wszczęcia postępowania, mającego ustalić, czy w konkretnym przypadku rzeczywiście doszło do popełnienia przestępstwa przeciwko wyborom), celem wydania opinii, Sąd Najwyższy rozpatruje w postępowaniu nieprocesowym, w składzie 3 sędziów ${ }^{49}$. Brak legitymacji do złożenia protestu lub uchybie-

45 Ibidem, s. 56. Dodatkowo podkreślić należy, że istotne jest rozróżnienie braków protestu w rozumieniu art. 130 k. p. c. od zachowania innych warunków, charakterystycznych już tylko dla protestów. Dlatego nie są brakami protestu w rozumieniu art. 130 k. p. c. zawarte w nim uchybienia, skutkujące pozostawieniem skargi bez dalszego biegu, co stanowi kompetencję SN, nie zaś przewodniczącego wydziału. Zakres odpowiedniego stosowania art. 130 k. p. c. w odniesieniu do protestów wyborczych będzie bardzo wąski (np. niepodpisanie protestu przez wnoszącego, niedołączenie odpowiedniej liczby kopii). Zob. K. Gołyński, op.cit., s. 26.

46 Z. Szonert, op.cit., s. 58.

47 J. Buczkowski, op.cit., s. 294. Por. także J. Repel, op.cit., s. 128.

48 W. Sanetra, Materialnoprawne przestanki protestów wyborczych, [w:] Wybory 93..., s. 75 .

49 A. Józefowicz, Czynności procesowe Sądu Najwyższego w sprawach protestów przeciwko ważności referendum konstytucyjnego, „Państwo i Prawo” nr 8, 1997, s. 69. Protest jest merytorycznie rozpatrywany na posiedzeniu niejawnym lub na rozprawie - decyzja w sprawie wyboru rodzaju posiedzenia należy do Sądu, zgodnie z dyspozycją art. 514 S 1 k. p. c. Por. A. Józefowicz, Przestanki..., s. 6 oraz Z. Szonert, op.cit., s. 58 oraz T. Flemming-Kulesza, A. Filcek, op.cit., s. 59. Zarządzenie rozprawy uzasadnione będzie np. w razie konieczności 
nie warunkom jego wniesienia, wynikającym z art. 79 ordynacji skutkuje pozostawieniem protestu bez dalszego biegu ${ }^{50}$. To samo dotyczy protestu wniesionego w sprawie, w której przepisy ustawy wyborczej przyznają skarżącemu możliwość wniesienia - przed dniem głosowania - skargi lub środka odwoławczego do sądu lub Państwowej Komisji Wyborczej. W nauce prawa spotykany jest pogląd, zgodnie z którym Sąd Najwyższy powinien rozpatrzyć protest wyborczy, oparty na zarzutach odnoszących się do rejestracji list lub kandydata na senatora, gdyby po dniu głosowania wykryto przestępstwo, polegające na sfałszowaniu podpisów poparcia dla danej listy (kandydata). Zarejestrowanie kandydata na podstawie sfałszowanego wykazu może bowiem wywrzeć wpływ na wynik wyborów. Przykładowo, w sytuacji, w której kandydat na senatora zarejestrowany dzięki sfałszowanym podpisom, uzyskał więcej głosów, niż wynosiła różnica pomiędzy kandydatem, który uzyskał mandat senatorski, a osobą, której głosów zabrakło. Podkreśla się również fakt, iż ordynacja wyborcza z 2001 r. przyznaje prawo zaskarżenia do sądu jedynie decyzji odmawiającej rejestracji listy lub kandydata na senatora, nie stwarza natomiast możliwości zaskarżenia przed dniem głosowania wadliwej rejestracji listy lub kandydata na senatora - zatem przypadek taki podlega ocenie SN dopiero na etapie stwierdzania ważności wyborów ${ }^{51}$. Podkreślić należy, iż protesty pozostawione bez dalszego biegu lub w stosunku do których postępowanie zostało umorzone ${ }^{52}$ nie stanowią, zgodnie $\mathrm{z}$ treścią art. 82 ust. 1 zd. pierwsze ordynacji wyborczej, podstawy do wydania uchwały w sprawie ważności wyborów. Sąd Najwyższy, w składzie całej Izby Pracy, Ubezpieczeń Społecznych i Spraw Publicznych opiera się bowiem na opiniach wydanych w wyniku rozpoznania protestów - te zaś dotyczą jedynie skarg merytorycznie rozpoznanych ${ }^{53}$.

przeprowadzenie postępowania dowodowego lub uzyskania od uczestników postępowania informacji niezbędnych dla Sądu.

so Jak wynika z praktyki wyborczej, jedną z najczęstszych przyczyn pozostawienia protestu bez dalszego biegu stanowi nieprzedstawienie zarzutów w rozumieniu ordynacji lub niewskazanie dowodów na ich poparcie. Por. K. Gołyński, op.cit., s. 29.

51 Por. S. Gebethner, op.cit., s. 112 . Podzielając w pełni drugi z wyrażonych poglądów, należy jednak stwierdzić, iż w przykładzie podanym przez S. Gebethnera protest wyborczy mógłby zostać oparty na zarzucie popełnienia przestępstwa przeciw wyborom określonego w art. 248 pkt $6 \mathrm{k}$. k.

52 Cofnięcie protestu przez skarżącego powoduje umorzenie postępowania.

53 Por. A. Józefowicz, Przesłanki..., s. 6 oraz J. Kwaśniewski, op.cit., s. 90. 
Uczestnikami postępowania są z mocy prawa: skarżący, przewodniczący właściwej komisji wyborczej ${ }^{54}$ lub jego zastępca oraz Prokurator Generalny. $\mathrm{Na}$ tle art. 80 ust. 3 ustawy, określającego krąg uczestników postępowania pojawiło się zagadnienie, czy katalog w nim przewidziany jest zamknięty, czy też możliwe jest wzięcie udziału w sprawie przez każdego zainteresowanego, którego praw o charakterze publicznoprawnym (związanych z czynnym i biernym prawem wyborczym) dotyczy wynik postępowania. Przyjęcie drugiej opcji skutkowałoby jednak zbytnim rozszerzeniem kręgu uczestników postępowania i dlatego należy uznać, że art. 80 ust. 3 ustawy przewiduje katalog zamknięty ${ }^{55}$. Opinia, wydawana $\mathrm{w}$ formie postanowienia (Sąd Najwyższy w postanowieniu z dnia 22 marca 2002 r. podkreślił, iż ordynacja wyborcza do Sejmu i Senatu z 2001 r. nie przewiduje możliwości zaskarżenia postanowień wydanych przez składy trójkowe SN w sprawach protestów wyborczych, ponieważ te formułujące opinie postanowienia stanowią następnie przedmiot oceny Sądu Najwyższego w składzie całej Izby [w obecnym stanie prawnym: Pracy, Ubezpieczeń Społecznych i Spraw Publicznych], która podejmuje na ich podstawie ostateczną decyzję w sprawie ważności wyborów $)^{56}$, może mieć dwojaki charakter: a) Sąd Najwyższy może ograniczyć się do stwierdzenia bezzasadności protestu, b) w przypadku uznania zarzutów za zasadne - jak wskazano powyżej - zadaniem Sądu jest ustalenie, czy stanowiące podstawę protestu przestępstwo przeciw wyborom bądź naruszenie przepisów ordynacji miały wpływ na ostateczny wynik wyborów ${ }^{57}$.

54 W cytowanym już opracowaniu sędziów SN dotyczącym zasad weryfikacji wyborów parlamentarnych pojęcie „właściwej komisji” postulowano ograniczyć jedynie do PKW oraz komisji okręgowych (zob. T. Flemming-Kulesza, A. Filcek, op.cit., s. 52) argumentując m.in., iż obwodowe komisje wyborcze rozwiązują się z chwilą zakończenia swych czynności. Jak podkreśla K. Gołyński, po pierwsze - treść art. 80 ust. 3 ordynacji wyborczej nie wyłącza z udziału w postępowaniu przewodniczącego obwodowej komisji wyborczej (lub jego zastępcy), po drugie zaś - „w niektórych przypadkach jedynie przewodniczący komisji obwodowej byłby w stanie wypowiedzieć się na temat słuszności zawartych w proteście zarzutów”. Por. K. Gołyński, op.cit., s. 23.

55 Tak m.in. T. Flemming-Kulesza, A. Filcek, op.cit., s. 52 oraz K. Gołyński, op.cit., s. 23.

56 Por. III AO 3/02, OSNP - wkł. 2002/13/4.

57 Zob. J. Kwaśniewski, op.cit., s. 85. Przy ocenie wpływu stwierdzonych naruszeń Sąd Najwyższy stosuje test polegający na zadaniu pytania, czy wykazane uchybienia - z obiektywnego punktu widzenia - nie spowodowały zmiany wyniku wyborów (tzn. nie spowodowały, że wynik wyborów był inny niż ogłoszony). Zob. K. Gołyński, op.cit., s. 27. Por. także orzeczenie Sądu Apelacyjnego w Katowicach z dnia 3 marca 1999 r. (I Acz 248/99, OSA 
Należy zwrócić uwagę na zmiany terminologiczne, odnoszące się do związku stwierdzonych naruszeń przepisów prawa wyborczego lub przestępstw wyborczych $\mathrm{z}$ wynikami przeprowadzonego postępowania wyborczego, jakie dokonywały się $\mathrm{w}$ treści kolejnych ordynacji wyborczych do Sejmu: ordynacje z 1989 i 1991 r. stanowiły, że przesłanką unieważnienia wyborów jest stwierdzenie, iż naruszenia prawa wyborczego lub przestępstwa przeciwko wyborom mogły mieć wpływ na ich wynik, zaś według postanowień ustawy z 1993 r., wskazane wyżej podstawy protestów uzasadniały podjęcie uchwały $\mathrm{w}$ sprawie unieważnienia wyborów, jeśli mogły mieć lub miały wpływ na ich ostateczny wynik. W trakcie wstępnych prac nad projektem kodeksu wyborczego podkreślano konieczność ujednolicenia w ustawach wyborczych przepisów, określających konieczny dla unieważnienia wyborów wpływ stwierdzonych naruszeń prawa wyborczego lub przestępstw wyborczych na ostateczny wynik postępowania. Jak podkreślano, „efektem dążenia do likwidowania różnic występujących obecnie w uregulowaniu podobnych instytucji prawnych jest w projekcie m.in. potraktowanie kwestii określenia przesłanek unieważnienia wyborów. W tej chwili tylko w przypadku wyborów do rad gmin przewiduje się, że do ich unieważnienia konieczne jest, aby przestępstwo lub inne naruszenie przepisów wywarło istotny wpływ na wynik głosowania; zgodnie z projektem kodeksu jest to przesłanka niezbędna do unieważnienia także innych wyborów (...). Tak więc wybory będą mogły zostać unieważnione tylko wówczas, gdyby przestępstwo przeciwko wyborom lub naruszenie przepisów kodeksu wyborczego wywarły istotny wpływ na wynik głosowania" ${ }^{58}$. Obecna wersja przepisu wymaga jednoznacznego stwierdzenia przez Sąd Najwyższy, czy naruszenia przepisów ordynacji wyborczej dotyczących głosowania, ustalenia wyników głosowania oraz ustalenia wyników wyborów lub przestępstwa wyborcze miały wpływ na wynik wyborów, tj. czy w ich następstwie mandaty uzyska-

1999/7-8/38), stanowiące ilustrację występującego w praktyce orzeczniczej poglądu, zgodnie z którym „nie każde naruszenie konkretnych przepisów ordynacji wyborczej prowadzić będzie do uznania wyborów za nieważne, aczkolwiek każde takie naruszenie stanowić może podstawę protestu wyborczego. Musi istnieć związek przyczynowo-skutkowy między owym naruszeniem ordynacji wyborczej, a wadliwością procesu głosowania i ustalenia wyników wyborów. Naruszenie ordynacji wyborczej tylko wtedy skutkować będzie nieważnością wyborów, gdy (...) doprowadziło w efekcie do wadliwego ustalenia wyników wyborów”. Zob. także K. Krzekotowska, op.cit., s. 31.

58 Por. A. Patrzałek, W. Skrzydło, op.cit., s. 19. 
ły inne osoby, niż te, które by je otrzymały, gdyby do naruszeń nie doszło ${ }^{59}$. Nieostry termin „mogły mieć wpływ na wynik wyborów” nie dawał szansy dokonania takich ustaleń - nie jest bowiem możliwe dokładne ustalenie procesów motywacyjnych, zachodzących w psychice wyborcy, w tym ustalenie czynników wpływających na podjęcie takiej, a nie innej decyzji w trakcie aktu głosowania.

Na podstawie opinii wydanych w sprawach wniesionych protestów wyborczych przez składy trzech sędziów ${ }^{60}$ (w doktrynie podkreśla się, iż w zależności od charakteru zarzutu podniesionego w proteście, weryfikacji dokonywanej przez SN w składzie całej Izby podlegać mogą zarówno ustalenia składów trzyosobowych dotyczące faktu naruszenia przepisów, jak również

59 S. Gebethner, op.cit., s. 109.

60 Należy zauważyć, iż w razie braku protestów wyborczych, jedyną - jak się wydaje podstawą uchwały w sprawie ważności wyborów będzie sprawozdanie przedstawione przez PKW. Tak m.in. J. Repel, op.cit., s. 129. Opinie wydawane przez składy trzech sędziów nie mają oczywiście charakteru wiążącego dla SN w składzie całej Izby podczas wydawania uchwały w sprawie ważności wyborów. Wskazany już powyżej brak możliwości zaskarżenia postanowienia wyrażającego opinię w sprawie zasadności protestu czyni je prawomocnym i ostatecznym wobec wszystkich uczestników postępowania, jednakże postanowienie takie nie zawiera ostatecznego rozstrzygnięcia istoty sprawy (por. J. Iwulski, Uchwała w sprawie ważności wyborów, [w:] Wybory 93..., s. 106), to bowiem zostało zarezerwowane dla Sądu działającego w składzie całej Izby, która może opinię składu trójkowego podzielić lub odrzucić (odmiennie J. Kwaśniewski, op.cit., s. 88 i n.). Sędzia J. Kwaśniewski wyraża pogląd, iż rozpoznanie protestu przez skład trzech sędziów SN oraz wydanie uchwały w sprawie ważności wyborów przez SN w składzie całej Izby to dwa odrębne od siebie postępowania, zróżnicowane ze względu na swój cel: w pierwszym przypadku SN działa jako organ wymiaru sprawiedliwości (podobnie K. Gołyński, op.cit., s. 10), zaś w drugim wykonuje „kompetencję szczególną, polegającą na nadawaniu prawomocności zakończonej akcji wyborczej”. Wątpliwości w odniesieniu do charakteru opinii wydawanych przez składy trzech sędziów SN wyraża M. Grzybowski, stawiając pytanie, czy działanie Sądu w omawianym zakresie określić można „sprawowaniem wymiaru sprawiedliwości” (rozumianym jako rozstrzyganie przez sądy konfliktów na tle stosowania prawa). Por. M. Grzybowski, Rola sądów i charakter orzeczeń sądowych w sprawach wyborczych, [w:] Trzecia wladza. Sady i trybunaty w Polsce, Materiały Jubileuszowego L Ogólnopolskiego Zjazdu Katedr i Zakładów Prawa Konstytucyjnego Gdynia, 24-26 kwietnia 2008 r., pod red. A. Szmyta, Gdańsk 2008, s. 355. Na nietypowy charakter rozstrzygnięcia w sprawie protestu wyborczego (nadanie mu formy opinii) zwraca uwagę P. Winczorek, Komentarz do Konstytucji RP z dnia 2 kwietnia 1997 r., Warszawa 2000, s. 239. Praktyka postępowania w sprawach wyborczych wskazuje, iż każdy z sędziów Izby Pracy, Ubezpieczeń Społecznych i Spraw Publicznych SN otrzymuje kopie wszystkich wydanych przez składy trójkowe postanowień wraz z uzasadnieniami, w celu ich bieżącej analizy z punktu widzenia zasadności podniesionych zarzutów oraz ich wpływu na wynik wyborów. Por. A. Józefowicz, Przestanki..., s. 7 oraz W. Sanetra, op.cit., s. 81. 
prawidłowość toku rozumowania przyjętego przez skład trójkowy ${ }^{61}$ oraz sprawozdania z wyborów przedłożonego przez Państwową Komisję Wyborczą, Sąd Najwyższy w składzie całej Izby Pracy, Ubezpieczeń Społecznych i Spraw Publicznych, z udziałem Prokuratora Generalnego i Przewodniczącego Państwowej Komisji Wyborczej, wydaje nie później niż w 90 dniu po dniu wyborów, uchwałę w sprawie ważności wyborów oraz ważności wyboru posła lub senatora, przeciwko któremu wniesiono protest.

Wątpliwości może budzić charakter prawny wskazanego w ustawie 90-dniowego terminu, w którym Sąd Najwyższy wydaje uchwałę w sprawie ważności wyborów. Sformułowanie „Sąd Najwyższy podejmuje, (...) nie później, niż w 90 dniu po dniu wyborów (... $)^{62}$ użyte w treści art. 82 ust. 2 ordynacji wyborczej mogłoby wskazywać na termin zawity (z takim stanem rzeczy mieliśmy do czynienia pod rządami uprzednio obowiązującej ordynacji sejmowej). W doktrynie prawa konstytucyjnego prezentowany jest pogląd, iż w rzeczywistości mamy do czynienia $\mathrm{z}$ terminem instrukcyjnym ${ }^{63}$. Trzeba mieć na uwadze, że wydanie orzeczenia stwierdzającego ważność wyborów parlamentarnych nie warunkuje ukonstytuowania się izb (inaczej, niż w przypadku wyborów prezydenckich, w których stwierdzenie ważności wyboru głowy państwa jest jedną z przesłanek objęcia urzędu) - Sejm i Senat mogą się zebrać na pierwsze posiedzenia przed wydaniem stosownej uchwały przez Sąd Najwyższy, a do czasu podjęcia przez SN rozstrzygnięcia w sprawie ważności wyborów, przedstawicielom przysługuje pełnia uprawnień wynikających z ustawy o wykonywaniu mandatu posła i senatora, tzn. mogą oni podejmować wszelkie czynności związane z wykonywaniem mandatu. Z tych względów - jak się wydaje - nie można wykluczyć możliwości podjęcia przez SN uchwały w sprawie ważności wyborów również po upływie 90-dniowego terminu, określonego w ordynacji. Stwierdzenie ważności

${ }^{61}$ Por. J. Repel, op.cit., s. 129. Odmiennie J. Kwaśniewski, który twierdzi, iż ze względów faktycznych i prawnych dotyczących podjęcia uchwały nie jest raczej możliwe weryfikowanie przez Izbę ustaleń składów trójkowych odnoszących się do stwierdzenia naruszeń prawa wyborczego. Por. J. Kwaśniewski, op.cit., s. 91.

${ }^{62} \mathrm{~W}$ odniesieniu do zasad obliczania 90-dniowego terminu określonego w art. 82 ust. 2 ordynacji wyborczej w przywoływanym powyżej opracowaniu sędziów SN wyrażono pogląd, iż zasadne wydaje się stosowanie w tym przypadku reguł wynikających z art. 111 \$ 1 i 2 k. c. oraz art. $165 \$ 1$ k. p. c., tj. do obliczania tego terminu nie należy uwzględniać dnia wyborów. Por. J. Iwulski, op.cit., s. 98 i n.

63 L. Garlicki, op.cit., s. 6. 
wyborów jest bowiem konstytucyjnie niezbędnym elementem postępowania wyborczego i jego pominięcie jest niedopuszczalne - tym bardziej nie może wynikać $\mathrm{z}$ interpretacji ustaw ${ }^{64}$.

Z terminem wynikającym z art. 82 ust. 2 ustawy wyborczej, wiąże się jeszcze jedno wymagające uwagi zagadnienie: należy pamiętać, iż w przypadku wniesienia protestu wyborczego opartego na zarzucie popełnienia przestępstwa przeciwko wyborom, postępowanie karne, mające na celu ustalenie, czy takie przestępstwo istotnie miało miejsce, toczy się niezależnie od postępowania przed Sądem Najwyższym. Dopiero prawomocny wyrok karny ostatecznie przesądza o zasadności zarzutów protestu, mającego za podstawę popełnienie przestępstwa wyborczego, objętego regulacją Rozdziału XXXI kodeksu karnego. Dlatego też, sąd powszechny powinien wydać prawomocne orzeczenie w takiej sprawie przed upływem 90-dniowego terminu, zakreślonego w ordynacji na podjęcie przez SN uchwały w sprawie ważności wyborów - wydaje się, że termin ten może się w wielu przypadkach okazać za krótki dla prawomocnego zakończenia postępowania przed sądem powszechnym (omawiane zagadnienie stanowi przedmiot istotnych rozbieżności wśród przedstawicieli nauki prawa: A. Józefowicz wyraża pogląd, że „ustalenie, czy popełniono przestępstwo (...) podlega samodzielnej ocenie Sądu Najwyższego, niezależnie od tego, jaki bieg nada zawiadomieniu o popełnieniu przestępstwa Prokurator Generalny". Zdaniem cytowanego Autora, SN powinien zbadać na rozprawie, czy zarzucany w proteście czyn został rzeczywiście dokonany, zaś w razie potwierdzenia zarzutu, Sąd Najwyższy powinien wydać postanowienie, wyrażające opinię w sprawie zasadności podstawy protestu. Jak twierdzi A. Józefowicz, nie występuje w omawianym przypadku konieczność zawieszenia postępowania toczącego się przed SN do czasu wydania zakończenia postępowania karnego, zaś wyrok karny „nie ma prejudycjalnego charakteru dla rozstrzygnięcia protestu" ${ }^{\prime}$.

Z wyrażonym poglądem - zwłaszcza w odniesieniu do braku prejudycjalności orzeczenia sądu karnego - trudno się zgodzić. Mając na uwadze przyjęty tryb rozpatrywania przez SN protestów wyborczych (postępowanie nieprocesowe, przy zastosowaniu przepisów k. p. c.) należy stwierdzić,

\footnotetext{
64 Ibidem, s. 6.
}

65 Por. A. Józefowicz, Czynności procesowe..., s. 74. Odmiennie T. Flemming-Kulesza, A. Filcek, op.cit., s. 67. Autorzy ci uważają, iż w razie wcześniejszego wydania wyroku karnego skazującego, SN byłby nim związany. 
iż wyłączona jest możliwość rozstrzygnięcia przez SN o popełnieniu przestępstwa $^{66}$. W odniesieniu do rozpatrzenia protestu opartego na ww. zarzucie przez skład trójkowy Sądu Najwyższego, podzielam stanowisko wyrażone w postanowieniu SN z dnia 16 listopada 2005 r. (sygn. akt III SW 120/05), zgodnie z którym „w razie wniesienia protestu zarzucającego popełnienie przestępstwa przeciwko wyborom, SN bada w postępowaniu cywilnym nieprocesowym zasadność tego zarzutu przy pomocy wskazanych w proteście środków dowodowych. Orzeczenie o popełnieniu przestępstwa może nastąpić tylko w odrębnym procesie karnym (...). Sąd Najwyższy w postępowaniu w sprawach protestów wyborczych ustala więc jedynie znamiona strony przedmiotowej ewentualnego przestępstwa przeciwko wyborom. Innymi słowy, SN ustala zasadność zarzutu popełnienia przestępstwa według znamion określonych w ustawie karnej. Ma to miejsce przy dokonywaniu ustaleń co do zasadności protestu i znajduje wyraz w wydanej opinii”. Podobny pogląd wyraża sędzia SN J. Kwaśniewski, który cytując uzasadnienie uchwały Trybunału Konstytucyjnego z dnia 14 lipca 1993 r. (W5/93), wykluczającej możliwość wydania przez SN orzeczenia o popełnieniu przestępstwa w postępowaniu związanym $\mathrm{z}$ wniesieniem protestu wyborczego, twierdzi, iż należy dopuścić możliwość wstępnego ustalenia zasadności zarzutów protestu przez skład trzech sędziów SN na podstawie znamion przestępstwa określonych w ustawie karnej. Autor ten podkreślił jednak równocześnie oczywistą nieodpowiedniość przepisów procedury cywilnej dla wyjaśnienia faktu popełnienie przestępstwa ${ }^{67}$. Na marginesie powyższych uwag należy stwierdzić, że z zestawienia terminów przewidzianych w prawie karnym dla prawomocnego zakończenia postępowania z 90-dniowym terminem na wydanie uchwały w sprawie ważności wyborów wynika, iż unieważnienie wyboru (ów) na podstawie protestu zarzucającego przestępstwo wyborcze jest mało realne ${ }^{68}$. Z problemem tym wiąże się jeszcze jedno zagadnienie: nawet przyjmując, iż SN byłby władny unieważnić wybory (wybór) na podstawie własnej oceny co do pełnienia przestępstwa, pojawia się

66 Tak m.in. J. Repel, który wyraża stanowisko, iż samo rozpatrzenie protestu opartego na zarzucie popełnienia przestępstwa wyborczego przez skład trzech sędziów będzie możliwe dopiero po uprzednim wydaniu orzeczenia karnego. Por. J. Repel, op.cit., s. 128 (podobnie Z. Szonert, op.cit., s. 58). Przyznaję, iż pogląd taki uznaję za zbyt rygorystyczny (zob. wyżej).

67 Por. J. Kwaśniewski, op.cit., s. 94.

68 Tak m.in. Z. Szonert, op.cit., s. 58. 
pytanie o konsekwencje późniejszego [po unieważnieniu wyborów] orzeczenia sądu karnego uniewinniającego domniemanego sprawcę) ${ }^{69}$. Być może warto rozważyć wprowadzenie odrębnego trybu postępowania sądowego w sprawach, w których od rozstrzygnięcia faktu, czy do popełnienia przestępstwa wyborczego rzeczywiście doszło, zależy wydanie uchwały w sprawie ważności wyborów?

Uchwała Sądu Najwyższego jest niezwłocznie przedstawiana Prezydentowi RP, Marszałkowi Sejmu lub Marszałkowi Senatu oraz Państwowej Komisji Wyborczej; podlega również ogłoszeniu w Dzienniku Ustaw Rzeczypospolitej Polskiej ${ }^{70}$. Treść uchwały podjętej przez Sąd Najwyższy decyduje o dalszym losie postępowania wyborczego - skutkiem uznania wyborów za ważne będzie jego zamknięcie, natomiast w przypadku podjęcia przez SN uchwały stwierdzającej nieważność wyborów, nieważność wyborów w okręgu lub nieważność wyboru konkretnego przedstawiciela, katalog dalszych czynności wyborczych zależy od zakresu unieważnienia.

W przypadku unieważnienia wyborów w całości, konieczne będzie przeprowadzenie postępowania wyborczego na nowo, w zakresie unieważnienia, na zasadach i w trybie przewidzianych ustawą. Mając na uwadze konsekwencje wynikające $\mathrm{z}$ unieważnienia wyborów (wygaśnięcie mandatów przedstawicielskich), należy stwierdzić, iż w przypadku podjęcia przez Sąd Najwyższy uchwały unieważniającej postępowanie wyborcze w skali całego kraju, izby wyłonione w drodze zakwestionowanych wyborów tracą legitymację do dalszego działania.

Z drugiej strony, mimo stwierdzenia w postępowaniu przed Sądem Najwyższym nieważności wyborów, wszystkie czynności podjęte przez izby przed dniem wydania przedmiotowej uchwały należy uznać za ważne, zgodnie $\mathrm{z}$ domniemaniem zgodnego z prawem przebiegu elekcji. Konsekwencje uznania przez Sąd Najwyższy nieważności wyborów w całości, budzą wątpliwości wśród przedstawicieli nauki prawa. Obok wyrażonego powyżej poglądu, zgodnie z którym izby, w razie stwierdzenia nieważności wyborów, tracą możliwość dalszego działania z dniem ogłoszenia uchwały SN z racji wygaśnięcia wszystkich mandatów przedstawicielskich, pojawiają się również pytania, co do możliwości powierzenia nieważnie wyłonionemu parla-

\footnotetext{
69 Por. K. Gołyński, op.cit., s. 19.

70 Uchwała w sprawie ważności wyborów ma charakter niewzruszalny i ostateczny. Por. J. Repel, op.cit., s. 130.
} 
mentowi pełnienia swych obowiązków do czasu przeprowadzenia wyborów ponownych lub powrotu - na okres przejściowy (do czasu nowych wyborów) poprzedniego, prawidłowo wybranego parlamentu ${ }^{71}$.

W odniesieniu do ewentualnego unieważnienia wyborów w skali okręgu (w wyborach do Sejmu) oraz unieważnienia wyboru konkretnego posła formułowane są liczne zastrzeżenia ${ }^{72}$. Bardzo wątpliwa, w warunkach systemu proporcjonalnego z ustaloną klauzulą zaporową, wydaje się być zarówno możliwość przeprowadzenia ponownych wyborów w skali jednego okręgu ( $\mathrm{z}$ racji ewentualnego wpływu na uprawnienia do udziału w podziale mandatów), jak również ponowny wybór pojedynczego posła ${ }^{73}$. Konsekwencje ponownych wyborów w skali jednego okręgu, mogące się wyrażać w utracie lub uzyskaniu prawa do udziału w podziale mandatów przez określone listy, prowadziłyby do trwającego aż do ponownego ustalenia wyników wyborów stanu „zawieszenia”, tymczasowości Sejmu ${ }^{74}$. Nie zmienia tego stanowiska fakt, iż zgodnie $\mathrm{z}$ art. 78 ust. 5 ordynacji, w razie wniesienia protestu wyborczego, w stosunku do wyłonionych przedstawicieli - aż do rozstrzygnięcia sprawy - zastosowanie znajdują przepisy o prawach i obowiązkach posłów i senatorów. Trafnie zauważa K. Gołyński, że zasada ta „tworzy (...) trudną do przyjęcia fikcję normalnej pracy Parlamentu, zwłaszcza jeżeli dotyczy zbyt wielkiej liczby członków Izby"75. Trudno przy tym wskazać ak-

71 Zob. np. L. Garlicki, op.cit., s. 7.

72 K. Gołyński, op.cit., s. 35.

73 S. Gebethner w komentarzu do ordynacji wyborczej z 2001 r. pisze, iż: „konsekwencje uchwały SN o nieważności wyborów w okręgu wyborczym bądź o nieważności wyboru posła lub senatora, mogą być dwojakiego rodzaju, w zależności od zakresu unieważnienia. Jeśli unieważnienie jest następstwem nieprawidłowości, do których doszło w trakcie głosowania, to zachodzi konieczność zarządzenia ponownych wyborów. Jeśli zaś do unieważnienia wyborów doszło wskutek nieprawidłowości w procesie ustalania wyników głosowania lub wyników wyborów, to nie ma konieczności zarządzania ponownych wyborów - można ograniczyć się do ponownego wykonania tych czynności bez potrzeby przeprowadzania jeszcze jednego głosowania. Zob. S. Gebethner, op.cit., s. 117. Uwagi te należy uznać za w pełni zasadne jedynie w odniesieniu do przypadków unieważnienia w skali okręgu wyborów do Senatu lub unieważnienia wyboru pojedynczego senatora. W warunkach systemu większościowego nie ma przeszkód do przeprowadzenia wyborów ponownych na obszarze pojedynczego okręgu lub w celu wyłonienia pojedynczego przedstawiciela. W wyborach sejmowych, $\mathrm{z}$ racji obowiązywania systemu proporcjonalnego, obarczonego klauzulą zaporową, takie rozwiązanie jest wątpliwe.

74 Por. K. Gołyński, op.cit., s. 35.

75 Ibidem, s. 35. 
ceptowalne środki zaradcze dla wskazanego problemu: wykluczone jest bowiem zarówno ponowienie wyborów w skali jednego okręgu, w ramach wcześniej ustalonego (przy okazji ustalania wyników wyborów częściowo unieważnionych) przez PKW katalogu list uprawnionych do partycypacji w podziale mandatów, jak również zastosowanie klauzuli zaporowej jedynie w odniesieniu do konkretnego okręgu. Wynika stąd wniosek, iż przeprowadzenie wyborów ponownych w skali jednego okręgu wyborczego (lub kilku okręgów) nie jest na gruncie obowiązującej ordynacji możliwe, zaś intencją ustawodawcy było prawdopodobnie zarezerwowanie ponownego głosowania jedynie do przypadku stwierdzenia nieważności wyborów we wszystkich okręgach ${ }^{76}$.

W odniesieniu do stwierdzenia nieważności wyboru pojedynczego posła, powtórzyć należy poczynione powyżej uwagi o niemożności obsadzenia mandatu w drodze wyborów ponownych, dodatkowo zaś wskazać trzeba brak podstaw do zastosowania art. 179 ust. 1 ordynacji (wstąpienie kolejnego kandydata $\mathrm{z}$ listy), z racji niewymienienia w art. 177 ust. 1 wśród przesłanek wygaśnięcia mandatu przypadku stwierdzenia nieważności wyboru przedstawiciela. Z powyższych względów, pod rządami obecnej ustawy wyborczej, zagadnienie uzupełnienia składu Sejmu z powodu unieważnienia wyboru posła należy uznać za nierozstrzygalne. Jak się wydaje, możliwym do zaakceptowania postulatem byłoby w tym przypadku poszerzenie katalogu przesłanek wygaśnięcia mandatu o przypadek unieważnienia mandatu poselskiego przez SN, co umożliwiłoby uzupełnienie składu parlamentu przez kolejnego kandydata z listy okręgowej (przypomnieć również można, że polskiemu prawu konstytucyjnemu znana była instytucja zastępcy posła, który w razie stwierdzenia nieważności wyboru przedstawiciela, wstępował $\mathrm{w}$ jego miejsce).

Wskazać jednak należy możliwe przypadki czynności wyborczych, na podstawie których - bez konieczności przeprowadzenia ponownego głosowania, można by usunąć przyczyny nieważności wyborów w okręgu lub wyboru posła oraz ustalić prawidłowe wyniki wyborów. Na przykład, w razie pominięcia w procesie ustalania wyników głosowania liczby głosów mającej wpływ na przydzielenie mandatu w obrębie jednej listy okręgowej (kandydat uzyskałby mandat, gdyby głosy te zaliczono jako oddane na niego), Sąd Najwyższy musiałby podjąć decyzję o unieważnieniu wyboru posłów z tej li-

$76 \quad$ Ibidem, s. 36. 
sty okręgowej oraz nakazać okręgowej komisji wyborczej ponowne ustalenie liczby oddanych głosów na poszczególnych kandydatów, skutkujące przydzieleniem mandatów uprawnionym. W przypadku, gdyby pominięta liczba głosów decydowała o rozdziale mandatów pomiędzy różnymi listami w ramach okręgu (jednakże przy założeniu, że liczba owych głosów pozostawałaby bez wpływu na przekroczenie progu wyborczego przez listę), Sąd Najwyższy powinien unieważnić wybory w tym okręgu i nakazać okręgowej komisji wyborczej ponowne ustalenie rozdziału mandatów. Pociągającą za sobą największe trudności sytuacją byłaby ta, gdyby pominięta liczba głosów wpływała na uzyskanie przez daną listę prawa do udziału w podziale mandatów, dzięki przekroczeniu klauzuli zaporowej. Wówczas unieważnienie wyborów w jednym okręgu wyborczym byłoby niewystarczające - Sąd Najwyższy musiałby podjąć uchwałę w sprawie stwierdzenia nieważności wyborów we wszystkich okręgach oraz nakazać Państwowej Komisji Wyborczej ponowne ustalenie komitetów wyborczych, których listy uprawnione byłyby do udziału w podziale mandatów. Okręgowe komisje wyborcze musiałyby dokonać ponownego podziału mandatów w okręgach ${ }^{77}$. Podsumowując powyższe uwagi, należy stwierdzić, iż w każdym z wymienionych przypadków, konsekwencją uchwały SN o nieważności wyborów lub wyboru będzie wygaśnięcie mandatu przedstawicielskiego (ze skutkiem na dzień jej ogłoszenia), jak również konieczność przeprowadzenia ponownych wyborów lub też powtórzenie postępowania wyborczego od określonej czynności. Od strony formalnej, obowiązujący stan prawny przewiduje nieznaczne różnice w dalszym przebiegu procesu wyborczego, w zależności od treści uchwały Sądu Najwyższego - i tak, w przypadku uznania postępowania wyborczego do Sejmu lub Senatu za nieważne w całości, zastosowanie znajdą przepisy ordynacji odnoszące się do zwykłego trybu przeprowadzenia wyborów, z zastrzeżeniem skróconych terminów wykonania czynności wyborczych, stosownie do nakazu odpowiedniego stosowania art. 10 ustawy (zgodnie z dyspozycją art. 10 ordynacji wyborczej, znajdującego zastosowanie w przypadku wcześniejszego zakończenia kadencji Sejmu, Prezydent RP zarządza wybory na dzień przypadający nie później niż w ciągu 45 dni od dnia wejścia w życie uchwały Sejmu o skróceniu swojej kadencji lub od dnia ogłoszenia postanowienia Prezydenta Rzeczypospolitej o skróceniu kadencji Sejmu, a skróceniu ulegają terminy: dokonywania zmian w podziale na obwody głosowania,

77 S. Gebethner, op.cit., s. 115 i n. 
tworzenia zamkniętych obwodów głosowania, zgłaszania sędziów do składów okręgowych komisji wyborczych, powoływania okręgowych komisji wyborczych, zawiadomienia o zamiarze zgłoszenia kandydatów na posłów lub senatorów oraz powołaniu pełnomocnika wyborczego i pełnomocnika finansowego dokonywanego przez organ partii politycznej pełniący funkcję jej komitetu wyborczego, zawiadomienia o utworzeniu komitetu wyborczego wyborców, utworzenia koalicyjnego komitetu wyborczego, podawania informacji o okręgu wyborczym przez Państwową Komisję Wyborczą, zgłaszania wniosków o wydanie przez PKW zaświadczenia o zarejestrowaniu list okręgowych w co najmniej połowie okręgów wyborczych, zgłaszania list okręgowych okręgowym komisjom wyborczym, wniesienia skargi do Sądu Najwyższego na postanowienie PKW odmawiające przyjęcia zawiadomienia o utworzeniu komitetu wyborczego, złożenia do PKW odwołania od postanowienia okręgowej komisji wyborczej odmawiającego zarejestrowania listy okręgowej, wniesienia odwołania do sądu okręgowego na postanowienie okręgowej komisji wyborczej odmawiające rejestracji listy okręgowej ze względu na niewystarczającą liczbę podpisów poparcia), jeżeli zaś stwierdzona zostanie nieważność wyborów w okręgu wyborczym, bądź nieważność wyboru posła lub senatora, wszelkie czynności postępowania wyborczego przeprowadza się jedynie na terenie kraju (również w tym przypadku odpowiednie zastosowanie znajduje art. 10 ordynacji), zaś na Państwowej Komisji Wyborczej ciąży obowiązek ogłoszenia obwieszczenia w sprawie wyników ponownych wyborów lub zarządzonych czynności wyborczych, ze wskazaniem osób, które w ich wyniku utraciły mandat przedstawicielski (wraz z numerem okręgu wyborczego, a w przypadku mandatu poselskiego również numeru i nazwy listy okręgowej) $)^{78}$. Obwieszczenie to podlega publikacji w Dzienniku Ustaw oraz podaniu do publicznej wiadomości ${ }^{79}$ (otrzymuje je również Marszałek właściwej izby). Ustawa nie określa, na

78 Treść art. 83 ust. 3 budzi liczne wątpliwości - PKW obowiązana jest wskazać osoby, które w wyniku ponownych wyborów lub na skutek podjęcia określonych czynności wyborczych utraciły mandat - tymczasem mandat wygasa przecież wcześniej, na skutek uchwały SN stwierdzającej nieważność wyboru (ów).

79 Kodeks wyborczy z dnia 3 grudnia 2010 r. (przed stanowiskiem Senatu) nakłada obowiązek podania do wiadomości publicznej w Biuletynie Informacji Publicznej zarówno postanowienia Prezydenta RP o wyborach ponownych lub podjęciu wskazanych czynności wyborczych, jak również obwieszczenia PKW o wynikach wyborów ponownych lub przeprowadzonych czynności wyborczych (por. art. 248 \$2, 248 \$ 4 i 249). 
podstawie jakich spisów wyborców miałyby się odbyć wybory ponowne obowiązujących podczas pierwotnie przeprowadzonego głosowania, czy też zaktualizowanych. Należy przyjąć, że sformułowanie art. 83 ust. 1 ordynacji wyborczej, nakazujące przeprowadzenie wyborów ponownych na zasadach i w trybie przewidzianym ustawą, przemawia za koniecznością aktualizacji spisów i objęcia nimi osób, które ukończą 18 rok życia najpóźniej w dniu, na który zostało wyznaczone głosowanie w wyborach ponownych.

\section{III.}

W odniesieniu do zasad ustalania ważności wyborów parlamentarnych po przemianach ustrojowych z 1989 r., przełom nastąpił wraz z przyjęciem Małej Konstytucji z 17 października 1992 r. Akt ten zerwał z trybem parlamentarnej kontroli prawomocności postępowania wyborczego na rzecz systemu jurysdykcyjnego, w którym organem wyłącznie właściwym do rozstrzygania o ważności wyborów ustanowiono Sąd Najwyższy. Wprowadzony na gruncie ustawy konstytucyjnej z 1992 r. model weryfikacji utrzymuje również obecnie obowiązująca Konstytucja RP z 2 kwietnia 1997 r.

Oceniając przyjęty tryb stwierdzania ważności postępowania wyborczego do Sejmu i Senatu, należy odnieść się do systemu kontroli jurysdykcyjnej z aprobatą - model weryfikacji wyborów, w którym rozstrzygnięcie o ich ważności należy do niezależnego i niezawisłego organu sądowego, zdaje się mieć $\mathrm{w}$ warunkach zasady podziału władz więcej zalet, niż nacechowana względami natury politycznej kontrola parlamentarna. Sąd Najwyższy, zarówno ze względu na poziom prawniczy swych członków, jak i z racji wysokiego autorytetu społecznego, daje wysokie prawdopodobieństwo podjęcia ostatecznej decyzji wyłącznie w oparciu o bezstronną analizę stanu faktycznego, przeprowadzoną w postępowaniu determinowanym treścią przepisów prawa.

Wyrażając jednoznacznie pozytywny stosunek do fundamentalnych założeń funkcjonującego współcześnie w polskich warunkach ustrojowych modelu weryfikacji wyborów, nie można jednak pominąć wątpliwości, jakie nasuwają się w odniesieniu do poszczególnych jego instytucji.

Jak wskazano powyżej, wśród najczęściej występujących zastrzeżeń co do możliwości praktycznego zastosowania rozwiązań przewidzianych przez 
obecny system weryfikacji wyborów, podkreślić należy wątpliwości odnoszące się do ewentualnego unieważnienia wyborów w skali jednego okręgu wyborczego (lub kilku okręgów), jak również dotyczące unieważnienia wyboru pojedynczego posła.

W pierwszym przypadku, wykluczone wydaje się powtórzenie wyborów ograniczonych jedynie do jednego okręgu, z racji obowiązywania systemu proporcjonalnego z zakreśloną klauzulą zaporową. Ponowienie głosowania tylko w jednym okręgu wyborczym spowodować by mogło konieczność ponownego ustalenia komitetów wyborczych, uprawnionych do udziału w podziale mandatów w skali całego kraju - wyniki ponownych wyborów w okręgu mogłyby bowiem skutkować utratą uprawnienia przez niektóre komitety lub jego uzyskaniem przez inne, w porównaniu z pierwotnie ustalonymi wynikami elekcji. Sytuacja taka powodowałaby swoistą tymczasowość Sejmu, trwającą do czasu ustalenia ostatecznych wyników wyborów. Nie wytrzymują próby praktycznego zastosowania ani postulaty ponowienia wyborów w skali okręgu w ramach układu sił wyznaczonego podczas ustalania wyników częściowo unieważnionych wyborów, ani też propozycje ustanowienia progu wyborczego jedynie w konkretnym okręgu. Przyjąć zatem należy, iż na gruncie obowiązującej ordynacji wyborczej nie jest realne unieważnienie wyborów w jednym lub kilku okręgach wyborczych, skutkujące koniecznością ponowienia głosowania.

Trudności nastręcza również udzielenie odpowiedzi na pytanie o sposób obsadzenia unieważnionego mandatu konkretnego posła. Ze względów przytoczonych powyżej (klauzula zaporowa) nie jest możliwe przeprowadzenie ponownych wyborów w odniesieniu do pojedynczego mandatu, brak również podstaw do uzupełnienia wakatu zgodnie z dyspozycją art. 179 ust. 1 ordynacji wyborczej.

$\mathrm{Z}$ powyższego wynika, iż pomimo że ustawodawca - formułując nakaz bezwzględnego przestrzegania ustalonych procedur wyborczych - wyposażył Sąd Najwyższy w prawne mechanizmy służące weryfikacji przeprowadzonych wyborów, to jednak - na gruncie rozwiązań funkcjonujących $\mathrm{w}$ przepisach prawa wyborczego (przyjęty system wyborczy sensu stricto, progi wyborcze) - zastosowanie części z nich w praktyce wydaje się wątpliwe.

Kolejnym zagadnieniem budzącym zastrzeżenia jest tryb rozpatrywania protestów wyborczych, opartych na zarzucie popełnienia przestępstwa wy- 
borczego. Pomijając przytoczone w artykule stanowiska skrajne, należy wyrazić pogląd, iż o ile możliwe wydaje się rozpoznanie przez skład trzech sędziów Sądu Najwyższego skargi wyborczej złożonej na wyżej wymienionej podstawie (rozumiem to jako dokonanie przez skład orzekający analizy wyczerpania lub niewyczerpania ustawowych znamion czynu), o tyle - moim zdaniem - niedopuszczalne jest wydanie przez Sąd Najwyższy w składzie całej Izby Pracy, Ubezpieczeń Społecznych i Spraw Publicznych uchwały unieważniającej wybory z powodu popełnienia przestępstwa wyborczego, bez wcześniejszego wyroku, zapadłego w odrębnym procesie karnym. Wiążące ustalenie faktu popełnienia przestępstwa nie może nastąpić w toku cywilnego postępowania nieprocesowego, w którym Sąd Najwyższy rozpatruje protesty wyborcze. Poza tym, rodzi się dodatkowo pytanie o wpływ wydanego przez sąd karny wyroku uniewinniającego domniemanego sprawcę przestępstwa, w razie wcześniejszego unieważnienia wyborów przez SN.

Omawiana sytuacja rodzi jeszcze jeden problem - prawomocne zakończenie postępowania karnego przed upływem wynikającego z ordynacji wyborczej 90-dniowego terminu do podjęcia uchwały w sprawie ważności wyborów przez Sąd Najwyższy jest bardzo mało prawdopodobne, dlatego też ewentualne unieważnienie postępowania wyborczego na podstawie protestów zarzucających popełnienie przestępstwa wyborczego rodzić może poważne trudności.

Pozostaje wyrazić nadzieję, że praktyka wyborcza wymusi przyjęcie rozwiązań udzielających odpowiedzi na większość wskazanych powyżej wątpliwości, nieprzekreślających jednak ogólnej pozytywnej oceny obowiązującego systemu stwierdzania ważności wyborów parlamentarnych - nie czyni tego niestety kodeks wyborczy w kształcie uchwalonym 3 grudnia $2010 \mathrm{r}$. (przed stanowiskiem Senatu). 


\section{Summary}

\section{Determining the validity of elections in accordance with the provisions of the Polish Constitution of 2 April 1997 and the Electoral Law in relation to Elections to the Sejm and the Senate of 12 April 2001}

Determination of the election validity is one of the most important elements in the electoral procedure, contributing significantly to legitimacy of the elected body. Institutions ensuring a fair election process, first of all, ensuring compliance of the results with the will of the sovereign. They constitute in contemporary times one of the key determinants of free elections, alongside democratic procedures for nominating candidates, free competition of political programs and opportunities for voters to express their will in the overt act of voting.

Based on the Polish constitutional law, several of the current election verification systems have been applicable. In relation to individual elements of each model, both positive assessments and critical remarks can be formulated. The following article focuses on explaining the rules for verification of Polish parliamentary elections under the current Constitution, together with the questions relating to the applicability of certain provisions of the adopted mode of the validation procedure for the election to the Sejm and the Senate. 